\title{
Uji Daya Hambat Ekstrak Etanol Bawang Putih Tunggal (Allium Sativum L.) terhadap Jamur (Candida Albicans)
}

\author{
Dahlia Andayani ${ }^{1}$ dan Rauhul A. Kurniawan ${ }^{1}$ \\ ${ }^{1}$ Jurusan Farmasi, Universitas Nahdlatul Wathan, Mataram, Indonesia
}

\begin{abstract}
Abstrak Bawang putih (Allium sativum L.) merupakan salah satu tumbuhan yang telah banyak dimanfaatkan selain sebagai bumbu dapur juga sebagai obat tradisional. Penelitian ini yang diuji adalah bawang putih siung tunggal yang diekstrak melalui proses maserasi dengan pelarut etanol 96\%. Penelitian ini merupakan penelitian true eksperimental dengan menggunakan ekstrak etanol bawang putih tunggal (Allium sativum L.) yang bertujuan untuk membuktikan apakah ekstrak etanol bawang putih tunggal tersebut memiliki kemampuan menghambat pertumbuhan jamur (Candida albicans). Ekstrak dibuat menjadi lima konsentrasi yaitu $20 \%, 40 \%, 60 \%, 80 \%, 100 \%$, selanjutnya dilakukan uji daya hambat pada jamur (Candida albicans) uji menggunakan metode sumuran dengan media SDA (Saboroud Dekstrose Agar). Hasil dari penelitian menunjukkan ekstrak etanol bawang putih dapat menghambat pertumbuhan jamur (Candida albicans) pada konsentrasi $100 \%, 80 \%, 60 \%, 40 \%$ dengan rata- rata diameter zona hambat dari masing-masing konsentrasi adalah 21,4 mm, 18,6 mm, 14,8 mm, dan 11,6 mm.Sedangkan konsentrasi $20 \%$ tidak menghasilkan zona hambat. Dari hasil penelitian terbukti ekstrak etanol bawang putih tunggal memiliki kemampuan menghambat pertumbuhan jamur (Candida albicans).
\end{abstract}

Kata kunci Bawang putih, etanol, pertumbuhan jamur.

\section{Pendahuluan}

Penyakit infeksi merupakan salah satu permasalahan dalam bidang kesehatan yang dari waktu ke waktu terus berkembang. Infeksi merupakan penyakit yang dapat ditularkan dari satu orang ke orang lain atau dari hewan ke manusia. Infeksi dapat disebabkan oleh berbagai mikroorganisme seperti virus, bakteri, jamur, riketsia, dan protozoa.(Gibson, 1996).

Patogenesis infeksi bakteri meliputi permulaan awal dari proses infeksi hingga mekanisme timbulnya tanda dan gejala penyakit. Ciri-ciri bakteri patogen yaitu kemampuan untuk menularkan, melekat pada sel inang, menginvasi sel inang dan jaringan, mampu untuk meracuni serta mampu untuk menghindar dari sistem kekebalan inang.Suatu penyakit terjadi jika bakteri atau reaksi imunologi yang ditimbulkannya menyebabkan suatu bahaya bagi seseorang, maka untuk menghambat daya infeksi agar tidak berkelanjutan lebih tinggi, bahkan kematian, perlu adanya antibakteri atau antibiotik sebagai obatnya (Jawetz et al., 2005).

Bagi negara-negara berkembang timbulnya bakteri yang resisten terhadap antibiotic menyebabkan angka kematian semakin meningkat.Selain itu cara pengobatan dengan menggunakan kombinasi berbagai antibiotik dapat menimbulkan masalah resisten yaitu munculnya bakteri yang multiresisten terhadap antibiotik. Bahaya terjadinya resisten kuman akan menyebabkan pengobatan penyakitmenjadi sulit dan lamanya sakit menjadi panjang, risiko timbulnya komplikasi atau kematian juga akan meningkat( Tjay dan Raharja, 2002 ).

Candida albicans merupakan penyebab penyakit infeksi. Candida albicans menimbulkan suatu keadaan yang disebut kandidiasis, yaitu penyakit pada selaput lendir mulut, vagina dan saluran pencernaan.Infeksi yang lebih gawat dapat menyerang jantung (endokarditis), darah (septisenia) dan otak (meningitis).Organisme ini dapat hidup sebagai sapropit pada selaput-selaput lendir tersebut di atas.Pada kebanyakan orang tanpa menyebabkan penyakit. Namun demikian apabila inangnya menjadi lemah karena suatu penyakit seperti misalnya pneumonia atau jika bakteri saingannya tertekan seperti pada pengobatan antibiotik yang berlanjut, Candida albicans dapat menyebabkan infeksi (Michael,J Pelczar., 2008).

Efek samping obat dan mahalnya biaya pengobatan menjadi beban serius bagi masyarakat.Dengan dorongan iklim " back to nature " maka desakan pengobatan itu diarahkan kepada pengobatan herbal (Anonim, 2005).

Obat tradisional merupakan obat-obatan yang diolah secara tradisional, turun-temurun, berdasarkan resep nenek moyang,adat istiadat,kepecayaan,atau kebiasaan setempat,baik bersifat magic maupun pengetahuan tradisional.

Bawang putih merupakan salah satu jenis tanaman yang tidak asing lagi dalam kehidupan sehari-hari dan mempunyai fungsi yang amat penting bagi kehidupan manusia.Disamping kegunaannya sebagai bumbu dapur, umbi bawang putih juga memiliki khasiat medik yang cukup besar dalam pengobatan tradisional.Di NTB sendiri, khususnya di Lombok, bawang putih merupakan salah satu komoditas pertanian yang berpotensi besar untuk dikembangkan.

Secara empiris, bawang putih tunggal sudah lama dikenal dan telah banyak dimanfaatkan. Bangsa Cina telah memanfaatkan bawang putih tunggal sejak tahun 510 Masehi untuk mengobati berbagai macam penyakit termasuk membasmi parasite, mengatasi masalah pernapasan,kelemahan sistem pencernaan, penambahan energi dan sistem peredaran darah.

Penelitian-penelitian mengenai khasiat bawang putih yang sudah banyak dilakukan umumnya menggunakan jenis bawang putih siung banyak, sedangkan di kalangan 
masyarakat tradisional di Indonesia seperti di Jawa dan Lombok sampai saat ini untuk pengobatan tradisional misalnya untuk mengobati asma dan sakit perut masyarakat menggunakan bawang putih yang hanya memiliki satu umbi yang disebut bawang putih siung tunggal yang dikenal di kalangan masyarakat petani sebagai " Kesuna Nunggal "( Samadi, 2000, Syamsiah dan Tajudin, 2003)

Kemampuan bawang putih tunggal ini berasal dari zat kimia yang dikandungnya yaitu allicin.Allicin adalah komponen utama yang berperan memberi aroma bawang putih dan merupakan salah satu zat aktif yang diduga dapat membunuh kuman-kuman penyakit (bersifat anti bakteri). Senyawa aktif didalam bawang putih tunggal mempunyai kemampuan sebagai antijamur (Candida albicans) dan antibakteri.

\section{Metode Penelitian}

Penyakit infeksi merupakan salah satu permasalahan dalam bidang kesehatan yang dari waktu ke waktu terus berkembang. Infeksi merupakan penyakit yang dapat ditularkan dari satu orang ke orang lain atau dari hewan ke manusia. Infeksi dapat disebabkan oleh berbagai mikroorganisme seperti virus, bakteri, jamur, riketsia, dan protozoa.(Gibson, 1996).

Patogenesis infeksi bakteri meliputi permulaan awal dari proses infeksi hingga mekanisme timbulnya tanda dan gejala penyakit. Ciri-ciri bakteri patogen yaitu kemampuan untuk menularkan, melekat pada sel inang, menginvasi sel inang dan jaringan, mampu untuk meracuni serta mampu untuk menghindar dari sistem kekebalan inang.Suatu penyakit terjadi jika bakteri atau reaksi imunologi yang ditimbulkannya menyebabkan suatu bahaya bagi seseorang, maka untuk menghambat daya infeksi agar tidak berkelanjutan lebih tinggi, bahkan kematian, perlu adanya antibakteri atau antibiotik sebagai obatnya (Jawetz et al., 2005).

Bagi negara-negara berkembang timbulnya bakteri yang resisten terhadap antibiotic menyebabkan angka kematian semakin meningkat.Selain itu cara pengobatan dengan menggunakan kombinasi berbagai antibiotik dapat menimbulkan masalah resisten yaitu munculnya bakteri yang multiresisten terhadap antibiotik. Bahaya terjadinya resisten kuman akan menyebabkan pengobatan penyakitmenjadi sulit dan lamanya sakit menjadi panjang, risiko timbulnya komplikasi atau kematian juga akan meningkat( Tjay dan Raharja, 2002 ).

Candida albicans merupakan penyebab penyakit infeksi. Candida albicans menimbulkan suatu keadaan yang disebut kandidiasis, yaitu penyakit pada selaput lendir mulut, vagina dan saluran pencernaan.Infeksi yang lebih gawat dapat menyerang jantung (endokarditis), darah (septisenia) dan otak (meningitis).Organisme ini dapat hidup sebagai sapropit pada selaput-selaput lendir tersebut di atas.Pada kebanyakan orang tanpa menyebabkan penyakit. Namun demikian apabila inangnya menjadi lemah karena suatu penyakit seperti misalnya pneumonia atau jika bakteri saingannya tertekan seperti pada pengobatan antibiotik yang berlanjut, Candida albicans dapat menyebabkan infeksi (Michael,J Pelczar., 2008).

Efek samping obat dan mahalnya biaya pengobatan menjadi beban serius bagi masyarakat.Dengan dorongan iklim " back to nature " maka desakan pengobatan itu diarahkan kepada pengobatan herbal (Anonim, 2005).

Obat tradisional merupakan obat-obatan yang diolah secara tradisional, turun-temurun, berdasarkan resep nenek moyang,adat istiadat,kepecayaan,atau kebiasaan setempat,baik bersifat magic maupun pengetahuan tradisional.

Bawang putih merupakan salah satu jenis tanaman yang tidak asing lagi dalam kehidupan sehari-hari dan mempunyai fungsi yang amat penting bagi kehidupan manusia.Disamping kegunaannya sebagai bumbu dapur, umbi bawang putih juga memiliki khasiat medik yang cukup besar dalam pengobatan tradisional.Di NTB sendiri, khususnya di Lombok, bawang putih merupakan salah satu komoditas pertanian yang berpotensi besar untuk dikembangkan.

Secara empiris, bawang putih tunggal sudah lama dikenal dan telah banyak dimanfaatkan. Bangsa Cina telah memanfaatkan bawang putih tunggal sejak tahun 510 Masehi untuk mengobati berbagai macam penyakit termasuk membasmi parasite, mengatasi masalah pernapasan,kelemahan sistem pencernaan, penambahan energi dan sistem peredaran darah.

Penelitian-penelitian mengenai khasiat bawang putih yang sudah banyak dilakukan umumnya menggunakan jenis bawang putih siung banyak, sedangkan di kalangan masyarakat tradisional di Indonesia seperti di Jawa dan Lombok sampai saat ini untuk pengobatan tradisional misalnya untuk mengobati asma dan sakit perut masyarakat menggunakan bawang putih yang hanya memiliki satu umbi yang disebut bawang putih siung tunggal yang dikenal di kalangan masyarakat petani sebagai "Kesuna Nunggal “( Samadi, 2000, Syamsiah dan Tajudin, 2003)

Kemampuan bawang putih tunggal ini berasal dari zat kimia yang dikandungnya yaitu allicin.Allicin adalah komponen utama yang berperan memberi aroma bawang putih dan merupakan salah satu zat aktif yang diduga dapat membunuh kuman-kuman penyakit (bersifat anti bakteri).Senyawa aktif didalam bawang putih tunggal mempunyai kemampuan sebagai antijamur (Candida albicans) dan antibakteri.

\section{Hasil dan Pembahasaan}

Hasil penelitian dapat dilihat dalam Tabel 1 untuk berbagai perlakuan 
Tabel 1. Diameter zona hambatan ekstrak etanol bawang putih tunggal (Allium sativum L.) terhadap pertumbuhan Jamur (Candida albicans).

\begin{tabular}{|c|c|c|c|c|c|c|c|c|}
\hline \multirow{2}{*}{ Perlakuan } & \multicolumn{5}{|c|}{ Replikasi } & \multirow{2}{*}{$\begin{array}{l}\text { Total } \\
\text { Perlakuan }\end{array}$} & \multirow{2}{*}{$\begin{array}{l}\text { Rata-rata } \\
\text { perlakuan }\end{array}$} & \multirow[t]{2}{*}{ Klasifikasi zona } \\
\hline & 1 & 2 & 3 & 4 & 5 & & & \\
\hline $\mathrm{T} 1$ & 21 & 21 & 22 & 20 & 23 & 107 & 21,4 & Kuat (sensitif) \\
\hline $\mathrm{T} 2$ & 18 & 19 & 18 & 18 & 20 & 93 & 18,6 & Sedang (sensitif) \\
\hline $\mathrm{T} 3$ & 14 & 16 & 15 & 15 & 14 & 74 & 14,8 & Lemah (Intermediat) \\
\hline $\mathrm{T} 4$ & 11 & 12 & 12 & 11 & 12 & 58 & 11,6 & Lemah (Intermediat) \\
\hline T5 & 0 & 0 & 0 & 0 & 0 & 0 & 0 & Tidak ada (resisten) \\
\hline Grand Total & & & & & & 332 & & \\
\hline Grand Mean & & & & & & & 66,4 & \\
\hline Kontrol (+) & & & & & & & $32 \mathrm{~mm}$ & \\
\hline Kontrol (-) & & & & & & & 0 & \\
\hline
\end{tabular}

Keterangan :

$1,2,3,4,5$ : Replikasi / ulangan

TP : Total Perlakuan

RP : Rata-rata Perlakuan

$\mathrm{T}_{1}$ : Konsentarasi ekstrak etanol bawang putih tunggal (Allium sativum L.) $100 \%$

$\mathrm{T}_{2}$ : Konsentrasi ekstrak etanol bawang putih tunggal (Allium sativum L.) $80 \%$

$\mathrm{T}_{3}$ : Konsentrasi ekstrak etanol bawang putih tunggal (Allium sativum L.) $60 \%$

$\mathrm{T}_{4}$ : Konsentrasi ekstrak etanol bawang putih tunggal (Allium sativum L.) $40 \%$

$\mathrm{T}_{5}$ : Konsentrasi ekstrak etanol bawang putih tunggal (Allium sativum L.) $20 \%$

Penelitian mengenai daya hambat ekstrak etanol bawang putih tunggal (Allium sativum L.) terhadap pertumbuhan jamur (Candida albicans) metode difusi sumuran Kirby Bauer menunjukkan bahwa terjadi penghambatan pertumbuhan jamur (Candida albicans) oleh ekstrak etanol bawang putih tunggal (Allium sativum L.) tersebut. Pada penelitian ini menggunakan sampel bawang putih tunggal (Allium sativum L.) yang diekstraksi secara maserasi. Proses maserasi diawali dengan pengeringan bawang putih tunggal (Allium sativum L.) sebanyak 500 gram diiric tipis-tipis dimasukkan kedalam oven dengan suhu $40^{\circ} \mathrm{C}^{\circ}$ selama 3 hari. Selanjutnya simplisia kering diubah bentuk menjadi lebih kecil dengan cara diblender. Simplisia kemudian dimasukkan ke dalam bejana maserasi direndam etanol 96\% selama 3 hari, kemudian diuapkan menggunakan evaporator sampai seluruh cairan penyari hilang dan diperoleh ekstrak kental.

Sebagai pelarut digunakan $\mathrm{NaCl} 0,9 \%$ agar ekstrak terlarut dengan homogen. Sampel dibuat dengan konsentrasi $100 \%, 80 \%, 60 \%, 40 \%, 20 \%$, lalu ditanam pada media Saboroud Dekstrose Agar (SDA) dengan ketebalan 4 mm. Media Saboroud Dekstrose Agar (SDA) digunakan sebab media ini paling efektif digunakan sebagai pertumbuhan jamur (Candida albicans). Pada media ini menggunakan tekhnik diswabkan Candida albicans koleksi Laboratorium Mikrobiologi RSU Propinsi NTB yang diperoleh dari pasien klinik (swab vagina/keputihan). Pada media yang telah diswabkan Candida albicans dibuat lubang sumuran dengan menggunakan blue tipe sebanyak replikasi yang diperlukan yaitu masing-masing 5 kali replikasi. Masing-masing sumuran diberi tanda sesuai dengan konsentrasi sampel. Pada masing-masing sumuran ditanam sampel sebanyak $50 \mu \mathrm{l}$. Merin kemudian diinkubasi pada incubator dengan suhu $37^{\circ}$ 'C' selama 24 jam, agar pertumbuhan Candida albicans optimal sebab apabila kurang dari 24 jam dapat mempengaruhi luas zona hambatan yang terbentuk. Seluruh proses penelitian dilakukan di dalam Laminar Air Flow (LAF) untuk menghindari kontaminasi dan sterilitasnya terjamin. Diameter zona hambatan diukur menggunakan mistar/penggaris dalam satuan millimeter ( $\mathrm{mm})$.

Dari hasil pengamatan setelah diinkubasi selama 24 jam pada tabel 5.1 penelitian ini menunjukkan zona hambatan pada kontrol positif (+) Nistatin yaitu $32 \mathrm{~mm}$, sedangkan pada T1,T2,T3,T4 dan T5 yaitu pemberian ekstrak etanol bawang putih tunggal (Allium sativum L.) dengan konsentrasi $100 \%$ menghasilkan nilai rata-rata zona hambatan sebesar 21,4 mm, konsetrasi $80 \%$ menghasilkan nilai rata-rata zona hambatan sebesar $18,6 \mathrm{~mm}$, konsentrasi $60 \%$ menghasilkan nilai rata-rata zona hambatan sebesar $14,8 \mathrm{~mm}$, konsentrasi $40 \%$ menghasilkan nilai rata-rata zona hambatan sebesar $11,6 \mathrm{~mm}$. Sedangkan pada konsentrasi $20 \%$ tidak menghasilkan zona hambatan.

Menurut pendapat Ahn dkk tahun 1994 yang menyatakan bahwa diameter zona hambatan yang dibentuk oleh bahan tradisional dikatakan sensitif kuat apabila zona hambatan lebih dari $20 \mathrm{~mm}$, dikatakan sensitif sedang apabila diameter zona hambatan antara 16-20 mm, dikatakan intermediet apabila diameter zona hambatan antara 10-15 $\mathrm{mm}$ dan dikatakan resisten apabila diameter zona hambatan 0 (nol). Dengan demikian konsentrasi ekstrak etanol bawang putih tunggal (Allium sativum L.) $100 \%$ bersifat sensitif kuat, konsentrasi ekstrak etanol bawang putih tunggal (Allium sativum L.) $80 \%$ dan $60 \%$ bersifat sensitif, konsentrasi ekstrak etanol bawang putih tunggal (Allium sativum L.) $40 \%$ bersifat lemah dan konsentrasi ekstrak etanol bawang putih tunggal (Allium sativum L.) $20 \%$ bersifat resisten. Dari kontrol antijamur Nistatin yang digunakan, dapat diketahui bahwa antijamur Nistatin tersebut bersifat sensitif kuat terhadap jamur (Candida albicans) karena diameter zona hambatan yang dihasilkan adalah $32 \mathrm{~mm}$.

Hal ini menandakan bahwa semakin rendah konsentrasi ekstrak etanol bawang putih tunggal (Allium sativum L.) yang digunakan maka zat aktif yang terkandung dalam bawang putih tunggal tersebut menjadi lebih sedikit sehinggazona hambatan yang dihasilkan semakin kecil. Selain itu menurut Soemarno (2000), ukuran diameter zona hambatan yang terbentuk dipengaruhi oleh factor-faktor seperti kekeruhan suspensi jamur, waktu peresapan, 
suspensi jamur ke dalam media SDA, suhu inkubasi, waktu inkubasi, ketebalan media dan komposisi media.

Dari tabel II menunjukkan hasil uji parametrik Kolmogorov-Smirnov untuk data hasil penelitian berupa diameter zona hambatan berdistribusi normal.Pada tabel 5.3 juga menunjukkan hasil uji Homogenitas Varians (Levene Statistik) untuk variabel penelitian bersifat homogen.

Berdasarkan tabel IV hasil uji Anova dengan tingkat kepercayaan $=95 \%$, diperoleh hasil yang signifikan yaitu probabilitas $(0,000)<\alpha(0,05)$. Hal ini menunjukkan bahwa ada daya hambat dari ekstrak etanol bawang putih tunggal (Allium sativum L.) terhadap pertumbuhan jamur (Candida albicans). Dengan demikian hipotesa yang menyatakan terdapat daya hambat ekstrak etanol bawang putih tunggal (Allium sativum L.) terhadap pertumbuhan jamur (Candida albicans) diterima.

Terbentuknya zona hambatan pada jamur yang diujikan disebabkan karena adanya zat-zat tertentu dalam ekstrak etanol bawang putih siung tunggal tersebut yang bersifat anti jamur.Kemampuan bawang putih sebagai anti jamur berasal dari zat kimia yang dikandungnya.Zat kimia yang terkandung pada bawang putih siung banyak juga terkandung pada bawang putih siung tunggal. Menurut Handayani (2006) allicin adalah komponen utama yang berperan memberi aroma bawang putih dan merupakan salah satu zat aktif yang juga berfungsi sebagai penghambat berbagai spesies jamur dan bakteri.Allicin berasal dari Allin bertemu dengan enzim alinase yang merubah allin menjadi allicin yang mengakibatkan bawang putih menjadi berbau dan mempunyai sifat antijamur. Allicin sangat reaktif dan tidak stabil sehingga dalam beberapa hari bisa diubah menjadi dialil sulfide, namun demikian allicinlah yang menyebabkan bawang putih berkhasiat sebagai obat.

Bawang putih merupakan salah satu tumbuhan obat yang mempunyai segudang khasiat, salah satunya sebagai antijamur.Beberapa penelitian menunjukkan bahwa bawang putih baik untuk melawan jamur Candida albicansyang biasa menyerang organ reproduksi wanita. Pernyataan tersebut dapat dibuktikan dengan penelitian sebelumnya yaitu Perbandingan daya antifungi ekstrak etanol bawang putih (Allium sativum) dan ketokonazol terhadap candida albicans secara in vitro (Heryu Prima Inayati Habib) yang menyatakan bahwa ekstrak bawang putih mempunyai daya antifungi terhadap candida albicans dan Uji banding efektivitas perasan umbi bawang putih (Allium sativum L.) $25 \%$ dengan ketokonazol $2 \%$ terhadap pertumbuhan candida albicanspada kandidiasis vaginalis( Aras Utami, 2006) yang menyatakan bahwa terdapat perbedaan yang bermakna antara efektivitas perasan umbi bawang putih $25 \%$ dengan ketokonazol $2 \%$ secara in vitro dalam menghambatpertumbuhan Candida albicans pada kandidiasis vaginalis. Zat alicin yang terkandung pada bawang putih siung banyak sama dengan bawang putih siung tunggal sehingga hal ini membuktikan bahwa bawang putih siung tunggal memiliki khasiat sebagai antijamur.

\section{Kesimpulan}

Berdasarkan hasil penelitian Uji Daya Hambat Ekstrak Etanol Bawang Putih (Allium sativum L.) terhadap Pertumbuhan Jamur (Candida albicans) dapat ditarik kesimpulan sebagai berikut :
1. Ekstrak etanol bawang bawang putih tunggal (Allium sativum $L$.) dapat menghambat pertumbuhan jamur (Candida albicans).

2. Ekstrak etanol bawang putih tunggal (Allium sativum L.) konsentrasi $100 \%, 80 \%, 60 \%$ dan $40 \%$ dapat menghambat pertumbuhan jamur (Candida albicans) dengan besar diameter zona hambatan rata-rata $21,4 \mathrm{~mm}, 18,6 \mathrm{~mm}$, 14,8 $\mathrm{mm}$ dan 11,6 mm. Sedangkan ekstrak etanol bawang putih tunggal (Allium sativum L.) konsentrasi $20 \%$ tidak mampu menghambat pertumbuhan jamur (Candida albicans), diameter zona hambatan nol.

Hasil penelitian ini secara keseluruhan memberikan gambaran mengenai potensi ekstrak etanol bawang putih tunggal (Allium sativum L.) dalam menghambat pertumbuhan jamur (Candida albicans) dengan daya hambat cukup besar (sensitif) sehingga perlu diteliti lebih lanjut mengenai identifikasi bahan bioaktif bawang putih tunggal (Allium sativumL.) dengan pelarut lainnya agar diketahui pelarut yang paling efesien. Selain itu juga penulis menyarankan kepada peneliti selanjutnya agar dapat membandingkan kandungan dan khasiat bawang putih tunggal dengan bawang putih siung banyak. Dan perlu dilakukan penelitian lebih jauh untuk mengisolasi senyawa aktif yang bersifat sebagai anti candida dari tanaman bawang putih tunggal dengan menggunakan metode ekstraksi yang lain seperti metode sokhletasi, perkolasi dan lain-lain.

\section{Daftar Pustaka}

Anonim, 1980,Materi Medika Indonesia jilid IV, 92-97, Depkes RI

Aras Utami. 2006. Uji Banding Efektivitas Perasan Umbi Bawang Putih (Allium sativum Linn.) 25\% Dengan Ketokonazol 2\% secara invitro Terhadap Pertumbuhan Candida albicans Pada Kandidiasis Vaginalis.http://www.google.co.id.

Bonang Gerard, 1982, Mikrobiologi Untuk Profesi Kesehatan. ED 14. EGC, Jakarta.

Bibiana, 1994.Teknik Biakan Murni: Teknik Agar Tuang. In: Analisa Mikroba di laboratorium, editor: Hastowo,Sugyo, ed.1,cet,.1.PT. Raja Grafido Persada Jakarta.

Cahyono, B. 1996.Penanaman Bawang Putih Dataran Tinggi. CV.Aneka Solo.

Ditjen POM, 1986. Sediaan Galenik,. Depkes RI.

Ditjen POM, 2000. Sediaan Galenik,. Depkes RI.

Dr.Prapti Utami. Antibiotik Alami untuk Mengatasi Aneka Penyakit. Jakarta: AgroMedia Pustaka, 2012.

FKUI.1993. Buku Ajar Mikrobiologi Edisi Revisi. Bina Rupa Aksara, Jakarta.

Hanafiah,KA.1997.Rancangan Percobaan Teori dan Aplikasi. Rajawali Perss, Jakarta.

Harborne J.B.,2006.Metode Fitokimia.ITB, Bandung.

Haryanto, Sugeng. 2009. Ensiklopedia Tanaman Obat Indonesia. Palmal: Yogyakarta.

Heryu Prima Inayati Habib. Perbandingan Daya Antifungi Ekstrak Bawang Putih (Allium sativum) Dan Ketokonazol Terhadap Candida albicans Secara In Vitro. http://www.google.co.id.

Irianto,K.2006.Mikrobiologi Ed 1.CV Yrama Widya Bandung 
Jawetz, E Melnick, J.L dan Adelberg EA. 1996. Mikrobiologi Kedokteran ED 20, EGC Jakarta.

Jawetz, E., J. C. Melnick dan E.A. Adelberg. 2001. Mikrobiologi Kedokteran. Salemba Medika Jakarta.

Jawetz, Melnick, \& Adelberg "S.2005.Mikrobiologi Kedokteran Buku 2, Salemba Medika.

Max Joseph Herman, 2001. Penyakit Hubungan Seksual Akibat Jamur, Protozoa, dan Parasit, Cermin Dunia Kedokteran No 130,2001

Michael J.Pelczaar Jr dan E.C.S. Chan.2008.Dasar-Dasar Mikrobiologi Jilid 1, UI Press, Jakarta.

Notoatmodjo S. 2002. Metodologi Penelitian Kesehatan. PT. Rineka Cipta, Jakarta.

Palungkun, Rony dan Asiani Budiarti. 1999. Bawang Putih Dataran Rendah. PT. Penebar Swadaya: Jakarta.

Syamsiah, IS. Dan Tajudin. 2003. Khasiat dan Manfaat Bawang Putih: Raja Antibiotik Alami. Agromedia Pustaka, Jakarta.

Soemarno. 2000. Isolasi dan Identifikasi Bakteri Klinik. AAK Yogyakarta, Departemen Kesehatan Republik Indonesia: Yogyakarta.

Syamsuni, H. A. Apt. Ilmu Resep. EGC: Jakarta. 